\section{Biology of the corneal endothelium in health and disease}

Eye (2003) 17, 912-918. doi:10.1038/

sj.eye. 6700559

Keywords: corneal endothelium; penetrating keratoplasty; ICE syndrome

\section{Introduction}

Our knowledge of the human corneal endothelium and our understanding of its role in maintaining vision have gradually increased. I will review here our current clinical concepts of the corneal endothelium. Owing to the space and time limitations, this must be a superficial review. You will notice perhaps an undue attention to studies conducted at the Mayo Clinic over the past 25 years. This is not

Department of

Ophthalmology

Mayo Clinic

Rochester, MN, USA

Correspondence:

WM Bourne

Department of

Ophthalmology

Mayo Clinic

200 First Street SW

Rochester MN 55905, USA

Tel.: + 1507284 3614;

Fax: + 1507284 8566;

E-mail: bourne@

mayo.edu

Received: 28 February 2003 Accepted in revised form: 28 February 2003

Supported in part by $\mathrm{NIH}$ Grant EY 02037, Research to Prevent Blindness, New York, NY, and Mayo Foundation, Rochester MN USA intended to imply an increased importance or superiority over similar investigations, but rather it is because of my familiarity with the Mayo Clinic studies.

\section{Endothelium in health}

The monolayer of cells called the corneal endothelium that lines the posterior corneal surface is derived from the neural crest during embryologic development. ${ }^{1}$ Human endothelial cell density is approximately 6000 cells $/ \mathrm{mm}^{2}$ during the first month of life, ${ }^{2}$ but decreases to about 3500 cells $/ \mathrm{mm}^{2}$ by age 5 years. ${ }^{3}$ Growth of the cornea accounts for some of this decrease in density, but a decrease in the number of cells also occurs. ${ }^{2}$ There is no evidence that human endothelial cells divide under normal circumstances, although they can be induced to divide in cultured corneas. ${ }^{4,5}$ They are arrested in the G1 phase of the cell cycle. ${ }^{6}$ The reason for the lack of progression into the cell cycle is still unknown, but it may involve cellular contact inhibition. ${ }^{7}$ Central endothelial cell density decreases throughout life at an average rate of about $0.6 \% /$ year $^{8}$ so that the mean cell density was found to decrease from 3400 cells $/ \mathrm{mm}^{2}$ at age 15 to 2300 cells $/ \mathrm{mm}^{2}$ at age 85 years. ${ }^{9}$ Racial or geographic differences appear to exist; higher cell densities were found in Japanese than in American subjects. ${ }^{10}$

The corneal endothelium secretes collagen that forms a basement membrane called Descemet's membrane. At the time of birth, Descemet's membrane is approximately $3 \mu \mathrm{m}$ thick and consists of collagen in a banded pattern with a periodicity of approximately $110 \mathrm{~nm} .{ }^{11}$ Throughout life, endothelial cells continue to secrete Descemet's membrane, but the collagen added after birth is not banded. By age 70 years, the average Descemet's membrane is $13 \mu \mathrm{m}$ thick, including the original $3 \mu \mathrm{m}$ of anterior banded (foetal) Descemet's membrane and an additional $10 \mu \mathrm{m}$ of posterior nonbanded Descemet's membrane. After age 70 years, the posterior nonbanded layer is thicker in females than in males. ${ }^{11}$ When the endothelial cells are stressed by damage or disease, they may secrete banded Descemet's membrane to form a posterior banded layer. ${ }^{12}$ This layer of abnormal Descemet's membrane has also been termed a posterior collagenous layer. ${ }^{13}$

The cornea is an exquisite example of natural engineering; the requirement for a living, optically clear lens on the surface of the eye was solved by packing collagen and cells in an orderly lamellar arrangement without blood vessels. The crystalline organization and critical spacing of collagen fibrils makes this tissue optically transparent. Any accumulation of fluid would disrupt this spacing and degrade the transparency. The endothelium must serve two functions to maintain the health and clarity of the stroma: it must control hydration (maintain stromal deturgescence) and it must be permeable to nutrients and other molecules 
from the aqueous humor because these are not supplied by blood vessels as they are in other tissues. This problem was solved by the development of an endothelial layer that behaves as a partial, or leaky, barrier to the movement of fluid and metabolic substrates. The endothelium maintains stromal deturgescence by functioning both as a barrier to fluid movement into the cornea and an active pump that moves ions, and draws water osmotically, from the stroma into the aqueous humor. These cells are metabolically very active, with large numbers of mitochondria, consistent with their need to move water efficiently. Endothelial cells have an incomplete zonula occludens, a leaky tight junction between adjacent cells, and this accounts for the weak endothelial barrier function that allows nutrients and other molecules to enter the stroma. The combined leaky barrier and fluid pump has sometimes been called a pump-leak mechanism. ${ }^{14}$ The barrier and pump functions can be measured clinically by fluorophotometry and pachometry. The barrier function can be estimated from the endothelial permeability to fluorescein. ${ }^{15}$ The efficiency of the pump can be studied by measuring the corneal deswelling rate from a $10 \%$ increase in thickness induced by $2 \mathrm{~h}$ of closed-eye aphakic soft contact lens wear. ${ }^{16}$ The endothelial pump rate can be calculated from the deswelling rate and the endothelial permeability. ${ }^{17}$

\section{Endothelium in disease}

\section{Primary corneal endotheliopathies}

There are relatively few primary corneal endothelial diseases, and a classification of primary corneal endotheliopathies devised 20 years ago ${ }^{18}$ is still appropriate (Table 1). The most common is Fuchs' dystrophy, an inherited bilateral disease in which the endothelial cells gradually malfunction. This condition becomes evident in middle age or later. The endothelial cell density is decreased, and the enlarged endothelial cells secrete excess amounts of abnormal banded Descemet's membrane. This abnormal tissue appears as drop-like warts (guttae) that project from the posterior surface of Descemet's membrane, and create the condition known as cornea guttata (guttate cornea). There is evidence that the pump function of the endothelium

Table 1 Primary corneal endotheliopathies

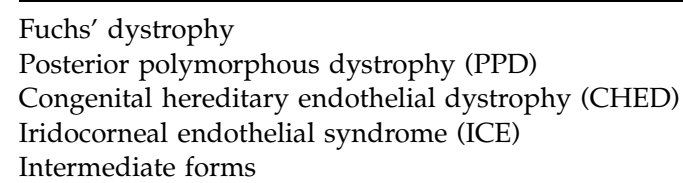

decreases first and is followed by a decrease in barrier function. ${ }^{19}$ When the endothelium is unable to maintain fluid balance, the cornea soon swells and loses its transparency. The only effective treatment at present is corneal transplantation. Recent evidence links the disorder to a mutation in the gene for collagen VIII. ${ }^{20}$

The second endothelial disease is a spectrum of inherited bilateral disorders called posterior polymorphous dystrophy (PPD). In these conditions, the endothelium contains epithelial-like cells. The abnormal cells may appear in isolated areas, across entire endothelium, or there may be intermediate involvement between these two extremes. ${ }^{21}$ The third primary corneal endotheliopathy, congenital hereditary endothelial dystrophy (CHED), is a bilateral disorder of the corneal endothelium like PPD, except that the entire endothelium is involved at birth so that the cornea is congenitally cloudy. There is some overlap between PPD and CHED, both pathologically, ${ }^{22,23}$ and genetically. ${ }^{24-27}$ A recent study found two families with Fuchs' dystrophy and a family with PPD with the same mutation in the gene for collagen VIII. ${ }^{20}$ Therefore, all three endothelial dystrophies may have genetic abnormalities in common.

A fourth primary endothelial disease is the iridocorneal endothelial (ICE) syndrome. This disorder is comprised of three syndromes that are now recognized to be varied manifestations of the same primary endothelial disease: essential iris atrophy, Chandler's syndrome, and Cogan-Reese iris nevus syndrome. The ICE syndrome is usually unilateral (although occasionally bilateral) and appears to be acquired. It is most common between 30 and 50 years of age and is more common in women. ${ }^{28}$ The endothelium has a beaten metal or cobblestone appearance and the cells have many characteristics of epithelial cells such as micovilli and cytokeratin markers ${ }^{29,30}$ and decreased permeability to fluorescein. ${ }^{31}$ On specular microscopy, these 'ICE cells' appear as the 'negative image' of normal endothelium; the cell junctions appear light and the cell bodies appear dark, a characteristic of epithelial cells ${ }^{32}$ (Figure 1). Although the endothelium is diffusely involved in most cases, occasionally the abnormal cells only occupy a portion of the cornea so that there is 'partial' ${ }^{\prime 33}$ or 'subtotal' ${ }^{34}$ involvement. In these cases, there is a sharp line of demarcation between the abnormal and normal endothelium (Figure 2) with the 'normal' cells being smaller than they are in an uninvolved cornea, creating a higher cell density in that area. The abnormal 'ICE-cells' spread peripherally onto the iris and form a membrane across the anterior chamber angle. This membrane can gradually contract and pull peripheral iris towards Schwalbe's line, forming small bridging synechiae that gradually enlarge. ICE 


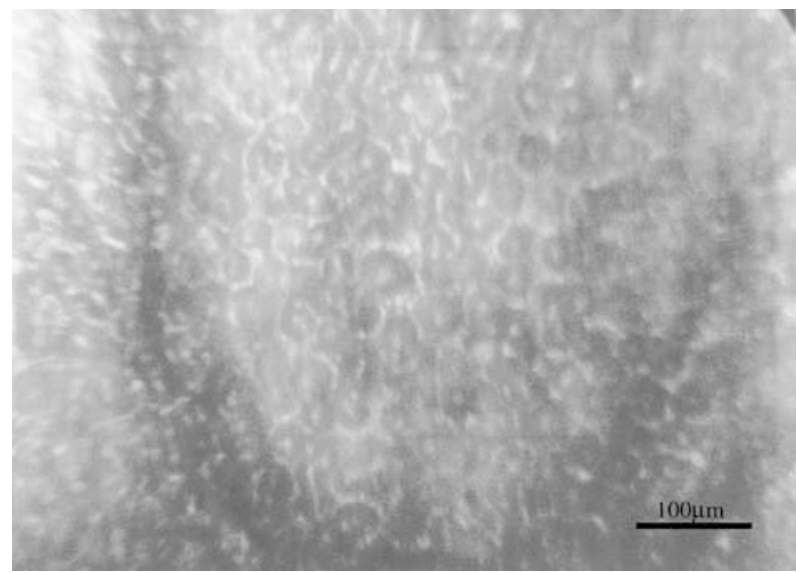

Figure 1 Appearance of abnormal endothelial cells in the iridocorneal endothelial (ICE) syndrome. These 'ICE cells' are enlarged and appear as the 'negative image' of normal endothelial cells; the cell junctions appear light and the cell bodies appear dark.

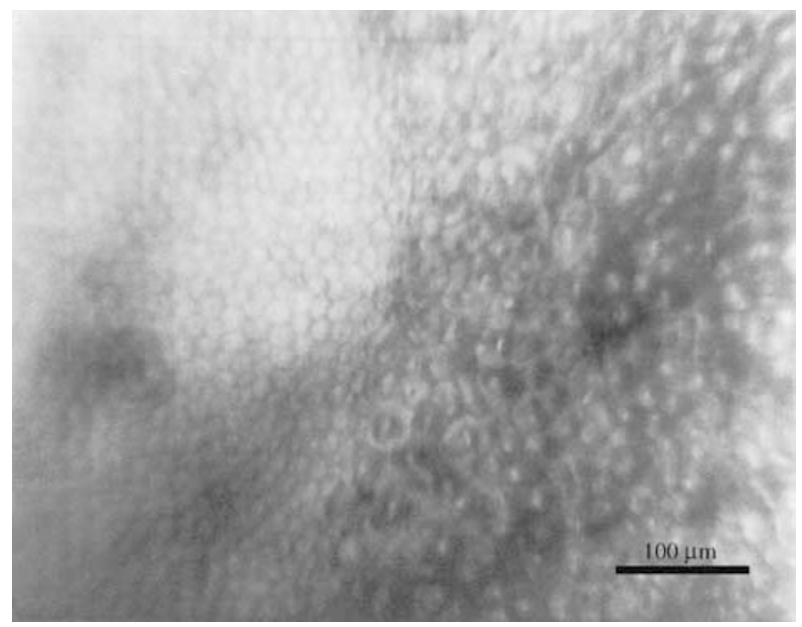

Figure 2 Partial corneal involvement in the iridocorneal endothelial (ICE) syndrome. A sharp junction is present between the abnormal 'ICE cells' on the right and the more normal endothelial mosaic on the left. The normal-appearing endothelial cells on the left are smaller than normal, and their density is 3634 cells $/ \mathrm{mm}^{2}$. Small bridging peripheral anterior synechiae were present.

cells can remain stable, increase and gradually spread over the entire cornea, or, in rare cases, they can gradually regress. ${ }^{35}$ The endothelium of the fellow eye is generally considered normal, but Lucas-Glass found polymegethism and pleomorphism with an unchanged cell density in the fellow eye. ${ }^{36}$ Others have noted similar changes in the fellow eyes. ${ }^{37,38}$

If one examines the endothelium of all patients carefully, occasional primary endothelial abnormalities are seen that do not fit the first four well-defined entities. I have called these primary corneal endotheliopathies of

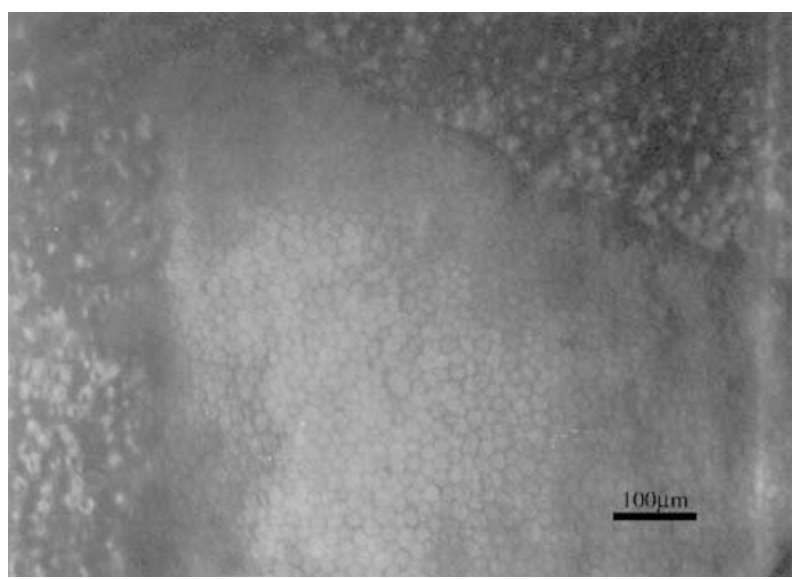

Figure 3 Intermediate form of primary corneal endotheliopathy in a 75-year-old man who was examined several times over the course of 13 years without detectable change. There is a sharp line of junction between the abnormal, cobblestoneappearing region with enlarged cells, and the more normal endothelial mosaic in which the cells are smaller than normal (cell density $=5607$ cells $/ \mathrm{mm}^{2}$ ). This patient had no iris abnormalities or peripheral anterior synechiae.

indeterminate type or intermediate forms (Table 1), since they often have features of both PPD and partial ICE syndrome, with no peripheral anterior synechiae (Figure 3). In the future, genetic testing of individuals with these intermediate forms may be diagnostic. It is possible that all primary corneal endotheliopathies share a similar genetic abnormality, since PPD, which shares genetic abnormalities with Fuchs' dystrophy and CHED (see above), has been linked to the ICE syndrome by some investigators. ${ }^{39-41}$ Alternatively, a nongenetic developmental anomaly may be at fault. Epithelialization may represent a single endothelial response to many different stimuli. ${ }^{42}$

\section{Secondary corneal endotheliopathies}

Contact lens wear Contact lens wear causes the endothelial cells to become more varied in size (polymegethism, an increase in the coefficient of variation of cell area), and in shape (pleomorphism a decreased percentage of hexagonal cells, Figure 4). These changes are thought to arise from hypoxia since they are not associated with oxygen-permeable silicone lenses. ${ }^{43}$ Extensive studies have failed to detect an effect of longterm contact lens wear on mean endothelial cell size or on endothelial barrier or pump function, as measured by fluorophotometry and deswelling. ${ }^{44}$

Endothelial effects of surgical procedures The effects of two surgical procedures, cataract extraction, and corneal 

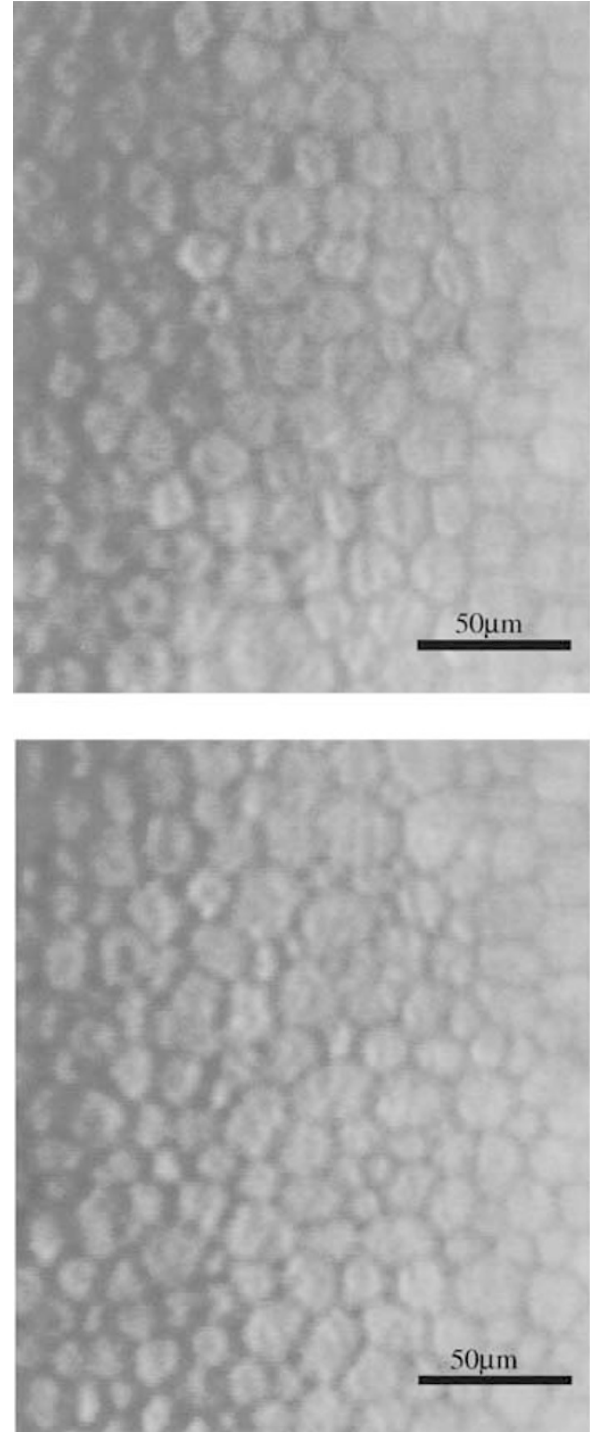

Figure 4 Polymegethism and pleomorphism induced by longterm contact lens wear. Top: endothelium of a 59-year-old 'normal' individual (the author) who has never worn contact lenses. Endothelial cell density $(E C D)=2131$ cells $/ \mathrm{mm}^{2}$, coefficient of variation of cell area $(\mathrm{CV})=22 \%$, percentage of hexagonal cells $(\mathrm{HEX})=73 \%$. Bottom: Polymegethism (increased $\mathrm{CV}$ ) and pleomorphism (decreased HEX) in the endothelium of a 54-year-old woman who has worn polymethylmethacrylate contact lenses for 34 years. $\mathrm{ECD}=3081$ cells $/ \mathrm{mm}^{2}, \mathrm{CV}=44 \%$. $\mathrm{HEX}=43 \%$.

transplantation, on corneal endothelial cells have been extensively studied. At 1-5 days after cataract extraction, a variable decrease in endothelial cell density was noted depending upon surgical trauma. ${ }^{45}$ After these initial cell losses, the endothelial cell density decreases at an average rate of $2.5 \%$ per year for at least 10 years after surgery, with or without a lens implant. ${ }^{46}$ This is four times the rate in unoperated eyes. ${ }^{8}$ The causes of this accelerated decrease in endothelial cell density after cataract extraction are unknown, although they may include decreased nutrition from aqueous humor that can bypass the pupil through a peripheral iridectomy, decreased innervation, increased subclinical inflammation, and exposure to vitreous humor.

In corneal transplantation (penetrating keratoplasty), the central recipient endothelium is replaced with the endothelium of an allogeneic donor cornea removed post mortem. After transplantation, endothelial cell density on these donor corneas is decreased by an amount that depends on the methods and duration of corneal storage and surgical trauma. For corneas preserved at $4^{\circ} \mathrm{C}$, the method used most commonly in the United States, there is a significant correlation between storage time and the decrease in cell density from the time before storage to the time after surgery, with corneas stored for longer periods having more cell loss. ${ }^{47,48}$ This relation between storage time and endothelial cell loss has also been found for corneas preserved by organ culture, the method most commonly used today in Europe. ${ }^{49}$ A major portion of cell loss can be attributed to apoptosis for both methods of storage. . $^{50,51}$

After transplantation, the endothelial cell density on the donor cornea decreases at a fairly rapid, but gradually decreasing, rate for several years. By 3 years $53 \%$ of the preoperative endothelial cell density is lost. ${ }^{52}$ The endothelial monolayer on the graft seems to spread during this time to cover the wound and the areas of peripheral damage. Studies have shown that endothelial cells can spread both from recipient to donor ${ }^{53}$ and from donor to recipient. ${ }^{54}$ Episodes of endothelial allograft rejection, although successfully aborted, cause a decrease in endothelial cell density. ${ }^{55}$ In our study of 500 consecutive penetrating keratoplasties performed between 1976 and 1986, transplants that had no known rejection episodes or reoperations lost central endothelial cells at average rates of 7.8\%/year between 3 and 5 years postkeratoplasty, and $4.2 \% /$ year between 5 and 10 years. ${ }^{56}$ Our most recent data on this long-term prospective study indicate that the rate of cell loss gradually decreases, but remains more than three times the normal loss of $0.6 \% /$ year $^{8}$ for 20 years postkeratoplasty. ${ }^{57}$

Figure 5 shows two examples of transplanted corneal endothelium observed for 20 years after keratoplasty for keratoconus. Endothelial cell density in one of the grafts gradually decreased at a rate similar to the average losses in corneal transplants. ${ }^{57}$ In the other graft, most of the donor endothelial cells did not survive. The graft was oedematous for months after keratoplasty, but it had cleared enough by 2 months for adequate specular microscopy, which showed a cell loss of $88 \%$ from the preoperative donor cell density. We know that the donor cornea was of poor quality because its mate failed after 
transplantation and was replaced (few endothelial cells remained when it was examined histologically). The central endothelial cell density of this graft from a poorquality donor (Figure 5) increased for 5 years to a density that was similar to the mean density in the other graft in Figure 5. Presumably, healthy recipient cells had spread onto the donor cornea. The endothelial cell density of both grafts decreased gradually for the subsequent 15 years. This is certainly atypical, since grafts that have low initial endothelial cell densities usually fail before those that do not (see below).

As the transplanted corneas age and the number of endothelial cells decreases, the corneas thicken. ${ }^{57}$ This is the result of decreased endothelial cell function. The pump activity of the enlarged endothelial cells on corneal transplants is markedly diminished despite an increased barrier function (decreased endothelial permeability to

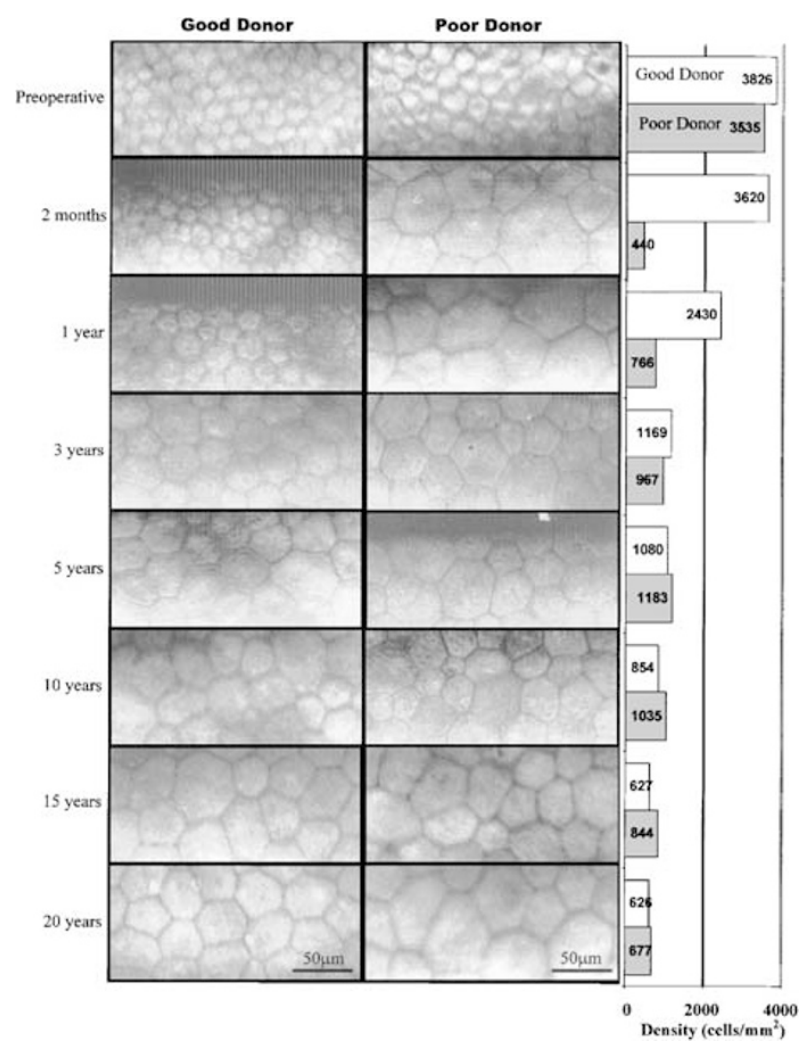

Figure 5 Sequential endothelial photographs for 20 years after transplantation of donor corneas of good and poor quality. The endothelial cell densities at each examination are shown on the right. Only $12 \%$ of the central endothelial cells of the poorquality donor remained 2 months postkeratoplasty. The central endothelial cell density of this graft gradually increased for 5 years, presumably from the spread of cells from the recipient cornea, until it became equal to that of the more normal graft on the left. The cell densities of the two grafts then decreased at similar rates for the next 15 years. This is atypical; grafts with fewer endothelial cells early after transplantation usually develop late endothelial failure earlier. ${ }^{61}$ fluorescein). ${ }^{58,59}$ This change in both the pump and permeability can be explained by the loss of total intercellular space. ${ }^{60}$ As endothelial function continues to deteriorate, the grafts can develop a condition, called late endothelial failure, characterized by persistent graft swelling and haze that is unresponsive to corticosteroids. ${ }^{61}$ Late endothelial failure accounts for more than $90 \%$ of graft failures after the first five postoperative years. ${ }^{56}$

Is a lower initial postoperative cell density or an accelerated loss of cells responsible for the extremely low cell densities that lead to late endothelial failure? In a series of 21 corneal transplants that developed late endothelial failure, we found that the rate of cell loss after the first 2 months was no different from that of the grafts that did not develop late endothelial failure. The initial endothelial cell density, however, both preoperatively and two months postoperatively, was significantly less than it was in the grafts that did not develop late endothelial failure. ${ }^{61}$ This suggests that improved corneal storage techniques or interventions that increase the postoperative endothelial cell density may decrease the rate of late endothelial failure and increase graft longevity. Three strategies in particular might be tried to improve endothelial cell survival. First, a molecule that inhibits apoptosis might be included in the preservative medium. Such a strategy improved the cell survival in cold-stored human livers. ${ }^{62}$ If posttransplant inhibition of apoptosis is needed, the transduction of cell survival genes such as $b c l-2$ or $p 35$ into the corneal endothelial cells could be accomplished during corneal storage ${ }^{63,64}$ Second, the number of endothelial cells on the donor cornea might be increased by the use of growth factors and the disruption of cellular contact inhibition. This strategy has been used to induce mitosis in human donor endothelial cells. ${ }^{5}$ Both of these strategies could be tested with human corneas in a xenograft model of transplantation ${ }^{65}$ and, if successful, could be easily incorporated into current methods of corneal preservation. Finally, improved methods of corneal preservation at low temperatures (cryopreservation) could eliminate the time-dependent deterioration of donor tissue during storage. ${ }^{66}$

\section{References}

1 Bahn CF, Falls HF, Varley GA, Meyer RF, Edelhauser HF, Bourne WM. Classification of corneal endothelial disorders based on neural crest origin. Ophthalmology 1984; 91: 558-563.

2 Bahn CF, Glassman RM, MacCallum DK, Lillie JH, Meyer $\mathrm{RF}$, Robinson BJ et al. Postnatal development of corneal endothelium. Invest Ophthalmol Vis Sci 1986; 27: 44-51.

3 Nucci P, Brancato R, Mets MB, Shevell SK. Normal endothelial cell density range in childhood. Arch Ophthalmol 1990; 108: 247-248. 
4 Senoo T, Joyce NC. Cell cycle kinetics in corneal endothelium from old and young donors. Invest Ophthalmol Vis Sci 2000; 41: 660-667.

5 Senoo T, Obara Y, Joyce NC. EDTA: a promoter of proliferation in human corneal endothelium. Invest Ophthalmol Vis Sci 2000; 41: 2930-2935.

6 Joyce NC, Navon SE, Roy S, Zieske JD. Expression of cell cycle-associated proteins in human and rabbit corneal endothelium in situ. Invest Ophthalmol Vis Sci 1996; 37: 1566-1575.

7 Joyce NC, Harris DL, Mello DM. Mechanisms of mitotic inhibition in corneal endothelium: contact inhibition and TGF- 32 . Invest Ophthalmol Vis Sci 2002; 43: 2152-2159.

8 Bourne WM, Nelson LR, Hodge DO. Central corneal endothelial cell changes over a ten-year period. Invest Ophthalmol Vis Sci 1997; 38: 779-782.

9 Yee RW, Matsuda M, Schultz RO, Edelhauser HF. Changes in the normal corneal endothelial cellular pattern as a function of age. Curr Eye Res 1985; 4: 671-678.

10 Matsuda M, Yee RW, Edelhauser HF. Comparison of the corneal endothelium in an American and Japanese population. Arch Ophthalmol 1985; 103: 68-70.

11 Johnson DH, Bourne WM, Campbell RJ. The ultrastructure of Descemet's membrane. I. Changes with age in normal corneas. Arch Ophthalmol 1982; 100: 1942-1947.

12 Johnson DH, Bourne WM, Campbell RJ. The ultrastructure of Descemet's membrane. II. Aphakic bullous keratopathy. Arch Ophthalmol 1982; 100: 1948-1951.

13 Waring III GO. Posterior collagenous layer of the cornea. Ultrastructural classification of abnormal collagenous tissue posterior to Descemet's membrane in 30 cases. Arch Ophthalmol 1982; 100: 122-134.

14 Maurice DM. The cornea and sclera. In: Davson H (ed.). The Eye, 3rd edn. Academic Press: Orlando; 1984, p. 85.

15 Carlson KH, Bourne WM, McLaren JW, Brubaker RF. Variations in human corneal endothelial cell morphology and permeability to fluorescein with age. Exp Eye Res 1988 47: 27-51.

16 Polse KA, Brand R, Mandell R, Vastine D, Demartini D, Flom R. Age differences in corneal hydration control. Invest Ophthalmol Vis Sci 1989; 30: 392-399.

17 Bourne WM, Hodge DO, McLaren JW. Estimation of corneal endothelial pump function in long-term contact lens wearers. Invest Ophthalmol Vis Sci 1999; 40: 603-611.

18 Bourne WM. Primary corneal endotheliopathies. Am J Ophthalmol 1983; 95: 852-853.

19 Wilson SE, Bourne WM, Brubaker RF. Effect of dexamethasone on corneal endothelial function in Fuchs' dystrophy. Invest Ophthalmol Vis Sci 1988; 29: 357-361.

20 Biswas S, Munier FL, Yaardley J, Hart-Holden N, Perveen R, Cousin $\mathrm{P}$ et al. Missense mutations in COL8A2, the gene encoding the $\alpha 2$ chain of type VIII collagen, cause two forms of corneal endothelial dystrophy. Hum Mol Gen 2001; 10: 2415-2423.

21 Krachmer JH. Posterior polymorphous corneal dystrophy: a disease characterized by epithelial-like endothelial cells which influence management and prognosis. Trans Am Ophthalmol Soc 1985; 83: 413-475.

22 Chan CC, Green WR, Barraquer J, Barraquer-Somers E, de la Cruz ZC. Similarities between posterior polymorphous and congenital hereditary endothelial dystrophies: A study of 14 buttons of 11 cases. Cornea 1982; 1: 155-172.

23 McCartney AC, Kirkness CM. Comparison between posterior polymorphous dystrophy and congenital hereditary endothelial dystrophy of the cornea. Eye 1988; 2(Part1): 63-70.

24 Tona NM, Ebenezer ND, Inglehearn CF, Plant C, Ficker LA, Bhattacharya SS. Linkage of congenital hereditary endothelial dystrophy to chromosome 20. Hum Mol Gen 1995; 4: 2395-2398.

25 Callaghan M, Hand CK, Kennedy SM, FitzSimon JS, Collum LM, Parfrey NA. Homozygosity mapping and linkage analysis demonstrate that autosomal recessive congenital hereditary endothelial dystrophy (CHED) and autosomal dominant CHED are genetically distinct. $\mathrm{Br}$ J Ophthalmol 1999; 83: 115-119.

26 Hand CK, Harmon DL, Kennedy SM, FitzSimon JS, Collum LM, Parfrey NA. Localization of the gene for autosomal recessive congenital hereditary endothelial dystrophy (CHED2) to chromosome 20 by homozygosity mapping. Genomics 1999; 61: 1-4.

27 Kanis AB, Al-Rajhi AA, Taylor CM, Mathers WD, Folberg RY, Nishimura DY et al. Exclusion of AR-CHED from the chromosome 20 region containing the PPMD and ADCHED loci. Ophthalm Paediatr Gen 1999; 20: 243-249.

28 Shields MB. Progressive essential iris atrophy, Chandler's syndrome, and the iris nevus (Cogan-Reese) syndrome: a spectrum of disease. Surv Ophthalmol 1979; 24: 3-20.

29 Kramer TR, Grossniklaus HE, Vigneswaran N, Waring GO, Kozarsky A. Cytokeratin expression in corneal endothelium in the iridocorneal endothelial syndrome. Invest Ophthalmol Vis Sci 1992; 33: 3581-3585.

30 Levy SG, McCartney ACE, Baghai MH, Barrett MC, Moss J. Pathology of the iridocorneal-endothelial syndrome. The ICE-cell. Invest Ophthalmol Vis Sci 1995; 36: 2592-2601.

31 Bourne WM, Brubaker RF. Decreased endothelial permeability in the iridocorneal-endothelial syndrome. Ophthalmology 1982; 89: 591-595.

32 Holliday JN, Buller CR, Bourne WM. Specular microscopy and fluorophotometry in the diagnosis of epithelial downgrowth after a sutureless cataract operation. Am J Ophthalmol 1993; 116: 238-241.

33 Bourne WM. Partial corneal involvement in the iridocorneal endothelial syndrome. Am J Ophthalmol 1982; 94: 774-781.

34 Levy SG, Kirkness CM, Moss J, Ficker L, McCartney AC. On the pathology of the iridocorneal-endothelial syndrome: the ultrastructural appearances of 'subtotal-ice.' Eye 1995; 9(Part3): 318-323.

35 Bourne WM, Brubaker RF. Progression and regression of partial corneal involvement in the iridocorneal endothelial syndrome. Am J Ophthalmol 1992; 114: 171-181.

36 Lucas-Glass TC, Baratz KH, Nelson LR, Hodge DO, Bourne WM. The contralateral corneal endothelium in the iridocorneal endothelial syndrome. Arch Ophthalmol 1997; 115: 40-44.

37 Hirst LW, Quigley HA, Stark WJ, Shields MB. Specular microscopy of iridocorneal endothelial syndrome. Am J Ophthalmol 1980; 89: 11-21.

38 Kupfer C, Kaiser-Kupfer MI, Datiles M, McCain L. The contralateral eye in the iridocorneal endothelial (ICE) syndrome. Ophthalmology 1983; 90: 1343-1350.

39 Hirst LW. Congenital anterior segment epithelialisation (CASE). Aust J Ophthalmol 1983; 11: 209-213.

40 Blair SD, Seabrooks D, Shields WJ, Pillai S, Cavanagh HD. Bilateral progressive essential iris atrophy and keratoconus with coincident features of posterior polymorphous dystrophy: a case report and proposed pathogenesis. Cornea 1992; 11: 255-261. 
41 Anderson NJ, Badawi DY, Grossniklaus HE, Stulting RD. Posterior polymorphous membranous dystrophy with overlapping features of iridocorneal endothelial syndrome. Arch Ophthalmol 2001; 119: 624-625.

42 Tetsumoto K, Kubota T, Rummelt V, Holbach LM, Naumann $\mathrm{GOH}$. Epithelial transformation of the corneal endothelium in forceps birth-injury-associated keratopathy. Cornea 1993; 12: 65-71.

43 Carlson KH, Ilstrup DM, Bourne WM, Dyer JA. Effect of silicone elastomer contact lens wear on endothelial cell morphology in aphakic eyes. Cornea 1990; 9: 45-47.

44 Bourne WM, Hodge DO, McLaren JW. Estimation of corneal endothelial pump function in long-term contact lens wearers. Invest Ophthalmol Vis Sci 1999; 40: 603-611.

45 Bourne WM, Brubaker RF, O'Fallon WM. Use of air to decrease endothelial cell loss during intraocular lens implantation. Arch Ophthalmol 1979; 97: 1473-1475.

46 Bourne WM, Nelson LR, Hodge DO. Continued endothelial cell loss ten years after lens implantation. Ophthalmology 1994; 101: 1014-1023.

47 Bourne WM. Corneal preservation: Past present and future. Refract Corneal Surg 1991; 7: 60-61.

48 Bourne WM, Nelson LR, Maguire LJ, Baratz KH, Hodge DO. Comparison of Chen medium and Optisol-GS for human corneal preservation at $4^{\circ} \mathrm{C}$. Results of transplantation. Cornea 2001; 20: 683-686.

49 Pels E, Schuchard Y. Organ-culture preservation of human corneas. Doc Ophthalmol 1983; 56: 147-153.

50 Komuro A, Hodge DO, Gores GJ, Bourne WM. Cell death during corneal storage at $4^{\circ} \mathrm{C}$. Invest Ophthalmol Vis Sci 1999; 40: $2827-2832$.

51 Albon J, Tullo AB, Aktar S, Boulton ME. Apoptosis in the endothelium of human corneas for transplantation. Invest Ophthalmol Vis Sci 2000; 41: 2887-2893.

52 Bourne WM, Hodge DO, Nelson LR. Corneal endothelium five years after transplantation. Am J Ophthalmol 1994; 118 185-196.

53 Bourne WM Penetrating keratoplasty with fresh and cryopreserved corneas. Donor endothelial cell survival in primates. Arch Ophthalmol 1978; 96: 1073-1074.
54 Olson RJ, Levenson JE. Migration of donor endothelium in keratoplasty. Am J Ophthalmol 1977; 84: 711-714.

55 Musch DC, Schwartz AE, Fitzgerald-Shelton K, Sugar A, Meyer RF. The effect of allograft rejection after penetrating keratoplasty on central endothelial cell density. Am J Ophthalmol 1991; 111: 739-742.

56 Ing JJ, Ing HH, Nelson LR, Hodge DO, Bourne WM. Ten-year postoperative results of penetrating keratoplasty. Ophthalmology 1998; 105: 1855-1865.

57 Bourne WM: Cellular changes in transplanted human corneas. Cornea 2001; 20: 560-569.

58 Bourne WM. Functional measurements on the enlarged endothelial cells of corneal transplants. Trans Am Ophthalmol Soc 1995; 93: 66-82.

59 Bourne WM. Clinical estimation of corneal endothelial pump function. Trans Am Ophthalmol Soc 1998; 96: 229-242.

60 Bourne WM, Brubaker RF. Decreased endothelial permeability in transplanted corneas. Am J Ophthalmol 1983; 96: 362-367.

61 Nishimura JK, Hodge DO, Bourne WM. Initial endothelial cell density and chronic endothelial loss rate in corneal transplants with late endothelial failure. Ophthalmology 1999; 106: 1962-1965.

62 Yagi T, Hardin JA, Valenzuela YM, Miyoshi H, Gores GJ, Nyberg SL. Caspase inhibition reduces apoptotic death of cryopreserved porcine hepatocytes. Hepatology 2001; 33: 1432-1440.

63 Reed JC. Bc1-2 and the regulation of programmed cell death. J Cell Biol 1994; 124: 1-6.

64 Clem RJ, Miller LK. Control of programmed cell death by the baculovirus genes p35 and iap. Mol Cell Biol 1994; 14: 5212-5222.

65 Ohno K, Mitooka K, Nelson LR, Hodge DO, Bourne WM. Keratocyte activation and apoptosis in transplanted human corneas in a xenograft model. Invest Ophthalmol Vis Sci 2002; 43: 1025-1031.

66 Armitage WJ, Hall SC, Routledge C. Recovery of endothelial function after vitrification of cornea at $-110^{\circ} \mathrm{C}$. Invest Ophthalmol Vis Sci 2002; 43: 2160-2164. 